\title{
HARMONIC POLYNOMIALS AND GENERALIZATIONS OF OSTROWSKI-GRÜSS TYPE INEQUALITY AND TAYLOR FORMULA
}

\author{
K. M. AWAN, J. PEČARIĆ AND A. VukElić
}

Abstract. Some generalizations of Ostrowski-Grüss type inequality and Taylor formula are given, by using harmonic sequences of polynomials. We use inequalities for the Čebyšev functional in terms of the first derivative (see [6]), for some new bounds for the remainders.

Mathematics subject classification (2010): 26D15, 26D20, 26D99.

Keywords and phrases: Čebyšev functional, harmonic polynomials, Ostrowski-Grüss inequality, Taylor formula.

\section{REFERENCES}

[1] M. Abramowitz And I. A. STEgun (Eds.), Handbook of mathematical functions with formulae, graphs and mathematical tables, National Bureau of Standards, Applied Math. Series 55, 4th printing, Washington 1965.

[2] G. A. Anastassiou, Ostrowski type inequalities, Proc. Amer. Math. Soc. 123 (1995), 3775-3781.

[3] P. Appell, Sur une classe de polnômes, Ann. Sci. Ecole Norm. Sup. 9, 2 (1880), 119-144.

[4] P. CERone, Three point rules in numerical integration, RGMIA, Research Report Collection 3, 2 (2000), 299-312.

[5] P. Cerone, S. S. Dragomir And J. Roumeliotis, Some Ostrowski's type inequalitiies for $n$-times differentiable mappings and applications, RGMIA, Research Report Collection 1, 1 (1988).

[6] P. CERone AND S. S. Dragomir, Some new bounds for the Čebyšev functional in terms of the first derivative and applications, J. Math. Ineq. 8, 1 (2014), 159-170.

[7] LJ. Dedić, M. Matić AND J. PeČARIĆ, On generalizations of Ostrowski inequality for Lipschitz. functions and functions of bounded variation, Math. Inequal. Appl. 3, 1 (2000), 1-14.

[8] Lu. Dedić, M. Matić And J. PeČARIĆ, On generalizations of Ostrowski inequality via some Eulertype identities, Math. Inequal. Appl. 3, 3 (2000), 337-353.

[9] Lu. Dedić, M. Matić, J. PeČArić And A. Vukelić, On generalizations of Ostrowski inequality via some Euler harmonic identities, J. Inequal. Appl. 7, 6 (2002), 787-805.

[10] S. S. DRAGOMIR AND S. WANG, An inequality of Ostrowski-Grüs type and its applications to the estimation of error bounds for some special means and for some numerical quadrature rules, Comput. Math. Appl. 33, 11 (1997), 16-20.

[11] S. S. DRAGOMIR, Better bounds in some Ostrowski-Grüss type inequalities, RGMIA, Research Report Collection 3, 1 (2000), 25-31.

[12] S. S. DRAGOMIR, New estimation of the Remainder in Taylor's Formula Using Grüss Type Inequalities and Applications, Math. Inequal. Appl. 2, 2 (1999), 183-193.

[13] S. S. DRAGomiR, An improvement of the remainder estimate in the generalised Taylor formula, RGMIA, Research Report Collection 3, 1 (2000), 3-8.

[14] A. M. FINK, Bounds on the deviation of a function from its averages, Czechoslovak Math. J. 42, 117 (1992), 289-310.

[15] M. Matić, J. PeČARIĆ AND N. Ujević, Improvement and further generalizations of some inequalities of Ostrowski-Grüss type, Computer. Math. Appl. 39 (2000), 161-175.

[16] M. Matić, J. PeČARIĆ AND N. Ujević, On new estimation of the remainder in generalized Taylor's formula, Math. Inequal. Appl. 2,3 (1999), 343-361. 
[17] G. V. Milovanović And J. E. PeČARIĆ, On generalizations of the inequality of A. Ostrowski and some related applications, Univ. Beograd. Publ. Eleektrotehn. Fak., Ser. Mat. Fiz., No. 544 -No. 576 (1976).

[18] D. S. Mitrinović, J. PeČArić And A. M. Fink, Inequalities Involving Functions and their Integrals and Derivatives, Kluwer Acad. Publ., Dordrecht, 1991.

[19] C. E. M. PeArCe, J. PeČArić, On Anastassiou's generalizations of the Ostrowski inequality and related results, J. Comput. Anal. Appl. 2, 3 (2000), 215-235.

[20] C. E. M. Pearce, J. PeČarić, S. VArošanec, Generalizations of some inequalities of OstrowskiGrüs type, Math. Ineq. Appl. 3, 1 (2000), 25-34.

[21] J. PeČARIĆ, S. VARošAnec, Harmonic Polynomials and generalizations of Ostrowski inequality with applications in numerical integration, Nonlin. Anal. 47 (2001), 2365-2374. 